\title{
Effect of Belimumab on Vaccine Antigen Antibodies to Influenza, Pneumococcal, and Tetanus Vaccines in Patients with Systemic Lupus Erythematosus in the BLISS-76 Trial
}

\author{
W. WINN CHATHAM, DANIEL J. WALLACE, WILLIAM STOHL, KEVIN M. LATINIS, SUSAN MANZI, \\ W. JOSEPH McCUNE, DANA TEGZOVÁ, JAMES D. McKAY, HILARIO E. AVILA-ARMENGOL, TAMMY O. UTSET,
} Z. JOHN ZHONG, DOUGLAS R. HOUGH, WILLIAM W. FREIMUTH, and THI-SAU MIGONE; on behalf of the BLISS-76 Study Group

\begin{abstract}
Objective. In patients with systemic lupus erythematosus (SLE), evidence suggests that most vaccines (except live-virus vaccines) are safe, although antibody response may be reduced. This substudy from the phase III, randomized, double-blind, placebo-controlled BLISS-76 trial evaluated the effects of belimumab on preexisting antibody levels against pneumococcal, tetanus, and influenza antigens in patients with SLE.

Methods. In BLISS-76, patients with autoantibody-positive, active SLE were treated with placebo or belimumab 1 or $10 \mathrm{mg} / \mathrm{kg}$ every 2 weeks for 28 days and every 28 days thereafter, plus standard SLE therapy, for 76 weeks. This analysis included a subset of patients who had received pneumococcal or tetanus vaccine within 5 years or influenza vaccine within 1 year of study participation. Antibodies to vaccine antigens were tested at baseline and Week 52, and percentage changes in antibody levels from baseline and proportions of patients maintaining levels at Week 52 were assessed. Antibody titers were also assessed in a small number of patients vaccinated during the study.

Results. Consistent with preservation of the memory B cell compartment with belimumab treatment, the proportions of patients maintaining antibody responses to pneumococcal, tetanus, and influenza antigens were not reduced. In a small group receiving influenza vaccine on study, antibody responses were frequently lower with belimumab, although titer levels were $>1: 10$ in all patients treated with $10 \mathrm{mg} / \mathrm{kg}$ and in the majority treated with $1 \mathrm{mg} / \mathrm{kg}$.

Conclusion. Treatment with belimumab did not affect the ability of patients with SLE to maintain antibody titers to previous pneumococcal, tetanus, and influenza immunizations. [ClinicalTrials.gov registration number NCT 00410384] (First Release June 15 2012; J Rheumatol 2012;39:1632-40; doi:10.3899/jrheum.111587)
\end{abstract}

Key Indexing Terms:

VACCINE

BELIMUMAB

SYSTEMIC LUPUS ERYTHEMATOSUS

INFLUENZA

TETANUS PNEUMOCOCCUS

From the Division of Clinical Immunology and Rheumatology, University of Alabama at Birmingham, Birmingham, Alabama; Cedars-Sinai Medical Center, Los Angeles, California; Division of Rheumatology, Los Angeles County + University of Southern California Medical Center and University of Southern California Keck School of Medicine, Los Angeles, California; Internal Medicine, Division of Rheumatology, University of Kansas Medical Center, Kansas City, Kansas; Department of Medicine, West Penn Allegheny Health System, Temple University School of Medicine, Pittsburgh, Pennsylvania; Internal Medicine, Division of Rheumatology, University of Michigan Medical Center - Regents of the University of Michigan, Ann Arbor, Michigan, USA; Institute of Rheumatology, Prague, Czech Republic; Oklahoma Center for Arthritis Therapy and Research, Tulsa, Oklahoma, USA; Instituto Jalisciense de Investigación Clínica, Guadalajara, Jalisco, Mexico; Internal Medicine, Division of Rheumatology, University of Chicago Pritzker School of Medicine, Chicago, Illinois; and Human Genome Sciences Inc., Rockville, Maryland, USA.

Supported by Human Genome Sciences Inc. (HGS), Rockville, Maryland, and GlaxoSmithKline (GSK), Uxbridge, Middlesex, United Kingdom. Dr. Chatham has received research or grant support and travel support from HGS. Drs. Wallace and Latinis have received consulting fees, speaking fees, and/or honoraria from HGS and GSK. Dr. Stohl has received clinical trial support from HGS. Dr. Manzi has received research grants and consulting fees from HGS. Dr. McCune has received research grants from $H G S$. Dr. Tegzová has received clinical trial support from HGS. Dr. McKay owns stock in HGS. Dr. Avila-Armengol has received clinical trial support from HGS. Dr. Utset has received speaking honoraria for general SLE lay education. Drs. Zhong, Hough, Freimuth, and Migone are employed by and own stock in HGS. Editorial support was funded by Human Genome Sciences and GlaxoSmithKline.

W.W. Chatham, MD, Division of Clinical Immunology and Rheumatology, University of Alabama at Birmingham; D.J. Wallace, MD, Cedars-Sinai Medical Center; W. Stohl, MD, PhD, Division of Rheumatology, Los Angeles County + University of Southern California Medical Center and University of Southern California Keck School of Medicine; K.M. Latinis, $M D, P h D$, Internal Medicine, Division of Rheumatology, University of Kansas Medical Center; S. Manzi, MD, MPH, Department of Medicine, West Penn Allegheny Health System, Temple University School of Medicine; W.J.McCune, MD, Internal Medicine, Division of Rheumatology, University of Michigan Medical Center - Regents of the University of Michigan; D. Tegzová, MD, Institute of Rheumatology, Prague; J.D. McKay, DO, Oklahoma Center for Arthritis Therapy and 
Research; H.E. Avila-Armengol, MD, Instituto Jalisciense de Investigación Clínica; T.O. Utset, MD, Internal Medicine, Division of Rheumatology, University of Chicago Pritzker School of Medicine; Z.J. Zhong, PhD; D.R. Hough, MD; W.W. Freimuth, MD, PhD; T-S. Migone, PhD, Human Genome Sciences.

Address correspondence to Dr. W.W. Chatham, Rheumatology FOT 802, University of Alabama-Birmingham, 1530 3rd Ave. South, Birmingham, AL 35294,USA.E-mail: wchatham@uab.edu

Full Release Article. For details see Reprint/Permissions at jrheum.org Accepted for publication April 16, 2012.

Available evidence suggests that vaccines (other than live-virus vaccines) are safe and effective in patients with systemic lupus erythematosus (SLE), although these patients may have reduced antibody responses to vaccination ${ }^{1}$. In a recent study by Mathian, et $a l^{2}$, patients with SLE who received 2 injections of a pandemic 2009 influenza A nonadjuvanted vaccine had $80 \%$ seroprotection and $72 \%$ seroconversion rates. The vaccine was well tolerated and did not increase disease activity, as assessed by several measures including the Safety of Estrogens in Lupus Erythematosus National Assessment-SLE Disease Activity Index (SELENA-SLEDAI); however, the response to vaccination was reduced in patients taking immunosuppressants. Belimumab is a human immunoglobulin (Ig)-G1 monoclonal antibody that has been shown to be effective in reducing SLE activity in patients with active disease in 2 phase III studies: BLISS- $52^{3}$ and BLISS- $76^{4}$. Belimumab blocks soluble B lymphocyte stimulator, a critical factor in B cell survival and differentiation ${ }^{5,6,7}$, from binding to its receptor on $\mathrm{B}$ cells ${ }^{8}$. In patients with SLE, belimumab has been shown to significantly reduce circulating CD19+, CD20+, naive, activated B cells and plasma cells, with memory cells transiently increasing and gradually returning to baseline levels over 76 weeks ${ }^{9}$. No significant differences in median $\mathrm{CD} 3+, \mathrm{CD} 3+/ \mathrm{CD} 4+$, or $\mathrm{CD} 3+/ \mathrm{CD} 8+\mathrm{T}$ cell counts were observed between patients treated with belimumab plus standard SLE therapy and those treated with standard therapy alone at 52 and 76 weeks of treatment. Levels of IgG were reduced by a median of $14 \%$ to $15 \%$ over 1 year of treatment ( $2 \%$ with placebo), with decreases being greater in patients with hypergammaglobulinemia at baseline. Because of the mechanism of action of belimumab, it was important to explore its effects on immune response to vaccines. Titers of antibodies against Streptococcus pneumonia, tetanus toxoid, and influenza antigens were measured before and after 52 weeks of treatment with belimumab or placebo, plus standard SLE therapy (including $56 \%$ of patients taking immunosuppressants), in patients with autoantibody-positive active SLE and history of vaccination against these pathogens who participated in BLISS-76 (ClinicalTrials.gov registration number NCT00410384) ${ }^{4}$. Responses to vaccines were also assessed in the small number of patients vaccinated during the study.

\section{MATERIALS AND METHODS}

Design overview. The BLISS-76 trial design is provided in detail elsewhere ${ }^{4}$. Briefly, BLISS-76 was a randomized, double-blind, 76-week trial in which 819 patients with active autoantibody-positive SLE (antinuclear antibody titer $\geq 1: 80$ or anti-dsDNA antibodies $\geq 30 \mathrm{IU} / \mathrm{ml}$ ) received standard therapy plus belimumab $1 \mathrm{mg} / \mathrm{kg}(\mathrm{n}=271)$ or $10 \mathrm{mg} / \mathrm{kg}(\mathrm{n}=273)$ or placebo $(n=275)$. Study medication was given every 2 weeks for the first 28 days and every 28 days thereafter. Patients with a SELENA-SLEDAI score $\geq 6$, receiving a stable regimen of standard therapy for $\geq 30$ days, and without severe active lupus nephritis or central nervous system lupus were enrolled in the study. The trial included progressive restrictions on concurrent medications.

The BLISS-76 study was compliant with the principles of the Declaration of Helsinki, and all participants provided written informed consent prior to study screening.

Setting, randomization, and patients. Patients were recruited from 136 medical centers located primarily in North America and Europe. Patients being treated with standard SLE therapies were randomly assigned in a $1: 1: 1$ ratio to receive placebo or belimumab $1 \mathrm{mg} / \mathrm{kg}$ or $10 \mathrm{mg} / \mathrm{kg}$, as described $^{4}$. At screening, history of previous pneumococcal, tetanus, or influenza vaccines was obtained from each patient. Patients who had received pneumococcal or tetanus vaccines within 5 years prior to the start of the study or influenza vaccine within 1 year were included in the vaccine substudy.

Outcomes and measurements. Patients who had received pneumococcal, tetanus, or influenza vaccines prior to study entry were tested for respective antibodies to vaccine antigens on Day 0 and at Week $52^{10,11,12}$. If a patient planned to receive a primary or booster dose of pneumococcal, tetanus, or influenza vaccine at any time during the study, a prevaccination blood sample was obtained to measure the prevaccination titer; in cases in which a sample was not obtained immediately prior to vaccination, the baseline sample was used to determine the prevaccination titer. In either case, a postvaccination antibody titer was drawn on the next study visit provided it had been 21 to 60 days from the time of vaccination.

A microsphere-based multianalyte immune detection system was used to measure IgG antibodies recognizing the pneumococcal polysaccharide antigens included in 12-valent conjugate vaccines. For each analyte, median fluorescent intensity values were converted to $\mu \mathrm{g} / \mathrm{ml}$ by interpolation from the relevant standard curve. The lower limit of quantitation (LLOQ) is $0.3 \mu \mathrm{g} / \mathrm{ml}$ for this assay; measurable levels of antibody are considered satisfactory for an immune response against a pneumococcal infection. Measurement of IgG antibodies recognizing tetanus toxoid was performed by ELISA with an LLOQ of $0.05 \mathrm{IU} / \mathrm{ml}$; antitoxoid $\mathrm{IgG}$ levels $\geq 0.50 \mathrm{IU} / \mathrm{ml}$ are generally considered sufficient to neutralize the toxoid. Hemagglutination inhibition tests were performed to detect influenza A- and B-specific responses (all Ig subclasses); a titer of 1:10 is considered adequate to suppress viral infection on this assay platform ${ }^{13}$. Relevant hemagglutination inhibition antigens for influenza vaccines administered in 2006-7, 2007-8, and 2008-9 (see Results) were tested in triplicate based on the patient's vaccination history. All 3 assays (i.e., pneumococcal, tetanus, and influenza) were performed at Focus Diagnostics Inc. (Cypress, CA, USA).

In patients with preexisting antibodies, the percentage changes in antibody levels from baseline and the proportions of patients who maintained antibody levels at Week 52 were assessed for all vaccines. For patients receiving influenza vaccine during the study, percentage changes in antibody levels from pre- to postvaccination measurements and proportions of patients who had postvaccination antibody titers $>1: 10$ were assessed.

For analysis of the memory B cell subset, peripheral blood lymphocytes were obtained at baseline and Weeks 8, 24, 52, and 76, and analyzed by flow cytometry using antibodies against CD20 and CD27 B cells ${ }^{9,14}$.

Statistical analysis. The percentage changes in antibody levels were compared between placebo and each belimumab group using the Wilcoxon test. The proportions of patients who maintained antibody levels were compared 
using the likelihood ratio chi-square test. When $>20 \%$ of the expected contingency table cell counts were $<5$, the proportions of patients who maintained antibody levels were analyzed using Fisher's exact test. Data on the small number of patients who received tetanus or pneumococcal vaccine during the study are summarized descriptively.

\section{RESULTS}

Patients. In all, 63 patients receiving placebo, 78 receiving belimumab $1 \mathrm{mg} / \mathrm{kg}$, and 63 receiving belimumab $10 \mathrm{mg} / \mathrm{kg}$ were assessed for changes in preexisting antigen-specific antibodies (Table 1); 30, 35, and 21 patients, respectively, were assessed for response to on-study vaccination, with the majority having received seasonal influenza vaccine. Baseline demographics across treatment groups were balanced, including disease activity and concomitant medications [immunosuppressants (methotrexate, azathioprine, and mycophenolate) were taken by $17 \%-22 \%$ of patients in each treatment group]. Overall, baseline demographics in the subgroups of patients who participated in the preexisiting or on-study vaccination substudy were representative of the general study population, except for higher proportions of patients enrolled from North America [79\%-91\% vs 50\% in BLISS-76, with, consequently, greater proportions of African Americans (16\%-21\% vs 14\%)], lower mean SELENA-SLEDAI scores (8.7-9.1 vs 9.7), and lower proportions receiving prednisone $>7.5 \mathrm{mg} /$ day $(31 \%-33 \%$ vs $46 \%$ ).

Effects on preexisting antibodies to vaccine antigens. Percentage changes in antipneumococcal $\mathrm{IgG}$ specific to the 12 antigens tested were similar across the 3 treatment groups at Week 52 (Figure 1). The percentages of patients

Table 1. Patients analyzed in the BLISS-76 vaccine substudy and baseline demographics.

\begin{tabular}{|c|c|c|c|}
\hline Characteristic & $\begin{array}{l}\text { dard Therapy }+ \\
\text { Placebo }\end{array}$ & $\begin{array}{c}\text { Standard Therapy }+ \\
\text { Belimumab } \\
1 \mathrm{mg} / \mathrm{kg}\end{array}$ & $\begin{array}{c}\text { Standard Therapy }+ \\
\text { Belimumab } \\
10 \mathrm{mg} / \mathrm{kg}\end{array}$ \\
\hline Preexisting antibody analysis, $\mathrm{n}$ & 63 & 78 & 63 \\
\hline Pneumococcal vaccine & 26 & 29 & 22 \\
\hline Tetanus vaccine & 35 & 34 & 26 \\
\hline Influenza vaccine & 44 & 61 & 39 \\
\hline \multicolumn{4}{|l|}{ Demographics } \\
\hline North America, n (\%) & $52(82.5)$ & $64(82.1)$ & $45(71.4)$ \\
\hline Western Europe/Israel, n (\%) & $8(12.7)$ & $10(12.8)$ & $11(17.5)$ \\
\hline Women, n (\%) & $59(93.7)$ & 74 (94.9) & $60(95.2)$ \\
\hline White, n (\%) & $48(76.2)$ & $52(66.7)$ & $43(68.3)$ \\
\hline Black/African American, n (\%) & $8(12.7)$ & $14(17.9)$ & $11(17.5)$ \\
\hline Mean age, yrs & 43.2 & 41.0 & 41.9 \\
\hline BILAG: $\geq 1$ A or $\geq 2$ B scores, $\mathrm{n}(\%)$ & $42(66.7)$ & $49(62.8)$ & $40(63.5)$ \\
\hline Mean SELENA-SLEDAI score & 8.8 & 9.4 & 9.2 \\
\hline Corticosteroids, n (\%) & $37(58.7)$ & $54(69.2)$ & $41(65.1)$ \\
\hline$>7.5 \mathrm{mg} /$ day, $\mathrm{n}(\%)$ & $19(30.2)$ & $28(35.9)$ & $20(31.7)$ \\
\hline Antimalarials, n (\%) & $49(77.8)$ & $52(66.7)$ & $40(63.5)$ \\
\hline Immunosuppressants, $\mathrm{n}(\%)$ & $34(54.0)$ & $48(61.5)$ & $37(58.7)$ \\
\hline Analysis of response to on-study vaccination, $n$ & 30 & 35 & 21 \\
\hline Pneumococcal vaccine* & 2 & 2 & 3 \\
\hline Tetanus vaccine $*$ & 2 & 2 & 1 \\
\hline Influenza vaccine & 30 & 39 & 24 \\
\hline \multicolumn{4}{|l|}{ Demographics } \\
\hline North America, n (\%) & $29(96.7)$ & $30(85.7)$ & $19(90.5)$ \\
\hline Western Europe/Israel, n (\%) & 0 & $5(14.3)$ & $2(9.5)$ \\
\hline Women, n (\%) & $26(86.7)$ & $31(88.6)$ & $21(100)$ \\
\hline White, n (\%) & $20(66.7)$ & $24(68.6)$ & $15(71.4)$ \\
\hline Black/African American, n (\%) & $7(23.3)$ & $8(22.9)$ & $3(14.3)$ \\
\hline Mean age, yrs & 42.7 & 40.7 & 41.7 \\
\hline BILAG: $\geq 1$ A or $\geq 2$ B scores, $\mathrm{n}(\%)$ & $19(63.3)$ & $22(62.9)$ & $11(52.4)$ \\
\hline Mean SELENA-SLEDAI score & 8.9 & 8.3 & 9.1 \\
\hline Corticosteroids, n (\%) & $18(60.0)$ & $27(77.1)$ & $11(52.4)$ \\
\hline$>7.5 \mathrm{mg} /$ day, n $(\%)$ & $9(30.0)$ & $12(34.3)$ & $6(28.6)$ \\
\hline Antimalarials, n (\%) & $26(86.7)$ & $21(60.0)$ & $15(71.4)$ \\
\hline Immunosuppressants, $\mathrm{n}(\%)$ & $14(46.7)$ & $21(60.0)$ & $16(76.2)$ \\
\hline
\end{tabular}

* Patients with data marked as both preexisting and on-study at different timepoints were analyzed in the on-study aspect of the study only. BILAG: British Isles Lupus Assessment Group index; SELENA-SLEDAI: Safety of Estrogens in Lupus Erythematosus National Assessment-Systemic Lupus Erythematosus Disease Activity Index. 


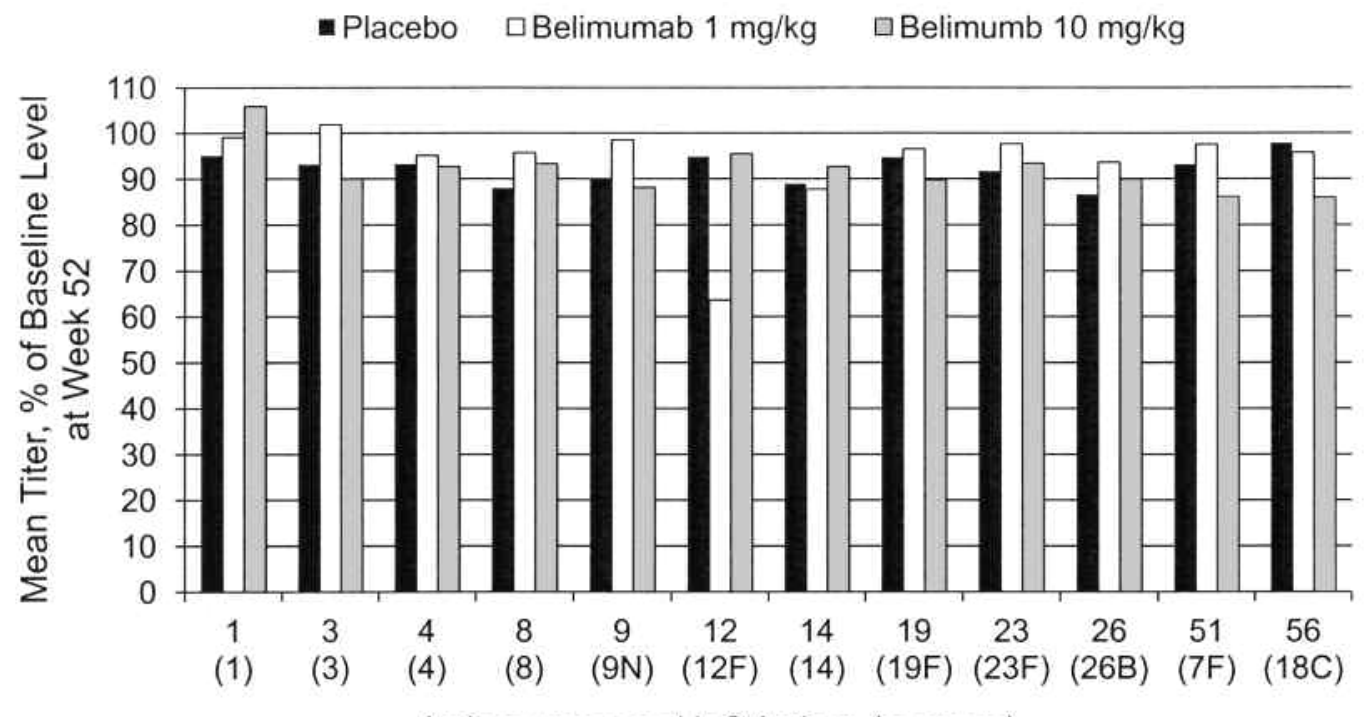

Antipneumococcal IgG Antigen (serotype)

Figure 1. Antipneumococcal immunoglobulin $\mathrm{G}(\mathrm{IgG})$ titers at Week 52 as percentages of baseline levels in patients who received pneumococcal vaccination prior to Day 0 and who were not revaccinated during the study.

who maintained measurable responses to serotypes (indicative of titers that should reduce the risk of infection on future exposure) were also similar across groups (Table 2). Percentage changes in antitetanus toxoid IgG and proportions of patients maintaining titers $\geq 0.50 \mathrm{IU} / \mathrm{ml}$ at Week 52 (indicative of titers that should reduce the risk of infection on future exposure) were similar across groups (Figure 2 and Table 2). For both antipneumococcal and antitetanus toxoid $\mathrm{IgG}$, some increases in titers were observed during treatment despite the absence of information identifying patients as having received vaccine on study. Percentage changes in antibodies to influenza antigens for the seasonal vaccine received in 2007-8 were not significantly different between treatment groups (Table 3 ). Some statistically significant differences in changes were observed for the vaccine received in 2006-7; these differences were associated with increases in antibody titers that occurred despite the absence of information indicating that patients had received vaccine while on study. These differences are not likely to represent clinically significant changes, because the median difference was $<1$ serial dilution of the sera. The proportions of patients who maintained antibody titer levels $>1: 10$ to influenza antigens at Week 52 (indicative of titers that should reduce the risk of infection on future exposure) were similar in all treatment groups (Table 2). No patients had received the 2008-9 seasonal vaccine prior to study participation.

Antibody response to on-study vaccination. In the 7 patients who received pneumococcal vaccine during the study, an increase was found 29-35 days after vaccination in antibodies to each of 12 tested antigens in 1 patient treated with placebo ( 4 of 4 serotypes with titer $<0.3$ converted to pro- tective titer $\geq 0.3)$; to 11 antigens in 2 patients with belimumab $1 \mathrm{mg} / \mathrm{kg}$ (5 of 6 serotypes converted in 1 patient; all serotypes were $>0.3$ prevaccination in the other patient), and 1 patient with belimumab $10 \mathrm{mg} / \mathrm{kg}$ ( 5 of 6 serotypes converted); to 10 antigens in 1 patient with placebo (3 of 5 serotypes converted) and in 1 patient with belimumab 10 $\mathrm{mg} / \mathrm{kg}$ ( 7 of 9 serotypes converted); and to 9 antigens in 1 patient with belimumab $10 \mathrm{mg} / \mathrm{kg}$ (7 of 10 serotypes converted). These findings are consistent with the observation that healthy subjects may not mount a response to all serotypes present in the vaccine ${ }^{15}$. Among 5 patients receiving tetanus vaccine on study, antibodies increased in 2 placebo patients; postvaccination antitoxoid IgG levels were $\geq 0.50 \mathrm{IU} / \mathrm{ml}$ in both, 1 of whom had such levels prevaccination. Each of the 3 patients with belimumab who received tetanus vaccine on study had antitoxoid IgG levels $\geq 0.50$ $\mathrm{IU} / \mathrm{ml}$ before and after vaccination. Tetanus antibody levels increased in 1 patient with belimumab $10 \mathrm{mg} / \mathrm{kg}$ and decreased in 1 patient with $1 \mathrm{mg} / \mathrm{kg}$; in the remaining patient with $1 \mathrm{mg} / \mathrm{kg}$, both pre- and postvaccination levels were greater than the upper limit of quantitation $(6.21 \mathrm{IU} / \mathrm{ml})$.

In all, 89 patients received influenza vaccine during the study. No patients with belimumab received the 2006-7 seasonal vaccine on study. Influenza vaccines given in consecutive years differ in only 1 or 2 of the virus strains; therefore, the majority of patients with vaccinations had preexisting titers to $\geq 1$ of the antigens tested. In patients receiving the 2007-8 influenza vaccine, antibodies to all antigens increased in all groups (the response data for 1 patient with belimumab $1 \mathrm{mg} / \mathrm{kg}$ were not available), with no significant differences in response (Table 4).

All groups also had increases to all antigens in the Personal non-commercial use only. The Journal of Rheumatology Copyright (C) 2012. All rights reserved. 
Table 2. Effect of placebo or belimumab plus standard therapy at Week 52 on preexisting antibody titers to pneumococcal, tetanus, and influenza vaccines in patients vaccinated prior to Day 0 and not revaccinated during the study.

\begin{tabular}{|c|c|c|c|}
\hline & $\begin{array}{l}\text { dard Therapy }+ \\
\quad \text { Placebo }\end{array}$ & $\begin{array}{c}\text { Standard Therapy }+ \\
\text { Belimumab } \\
1 \mathrm{mg} / \mathrm{kg}\end{array}$ & $\begin{array}{c}\text { Standard Therapy + } \\
\text { Belimumab } \\
10 \mathrm{mg} / \mathrm{kg}\end{array}$ \\
\hline Pneumococcal vaccine antigen, $\mathrm{n}^{\dagger \dagger}$ & 26 & 27 & 22 \\
\hline $\begin{array}{l}1 \text { (1): no. with titer } \geq \text { LLOQ/no. } \\
\text { with level } \geq \text { LLOQ at baseline }(\%)^{*}\end{array}$ & $10 / 12(83)$ & $20 / 23(87)$ & $12 / 13(92)$ \\
\hline $\begin{array}{l}3 \text { (3): no. with titer } \geq \text { LLOQ } / \text { no. } \\
\text { with level } \geq \text { LLOQ at baseline (\%)* }\end{array}$ & $18 / 20(90)$ & $19 / 20(95)$ & $15 / 15(100)$ \\
\hline $\begin{array}{l}4 \text { (4): no. with titer } \geq \text { LLOQ } / \text { no. } \\
\text { with level } \geq \text { LLOQ at baseline }(\%)^{*}\end{array}$ & $9 / 10(90)$ & $17 / 18(94)$ & $5 / 6(83)$ \\
\hline $\begin{array}{l}8 \text { (8): no. with titer } \geq \text { LLOQ } / \text { no. } \\
\text { with level } \geq \text { LLOQ at baseline }(\%)^{*}\end{array}$ & $17 / 17(100)$ & $21 / 21(100)$ & $16 / 18(89)$ \\
\hline $\begin{array}{l}9(9 \mathrm{~N}): \text { no. with titer } \geq \mathrm{LLOQ} / \text { no. } \\
\text { with level } \geq \text { LLOQ at baseline }(\%)^{*}\end{array}$ & $17 / 17(100)$ & $21 / 21(100)$ & $12 / 13(92)$ \\
\hline $\begin{array}{l}12(12 \mathrm{~F}) \text { : no. with titer } \geq \text { LLOQ } / \text { no. } \\
\text { with level } \geq \text { LLOQ at baseline }(\%)^{*}\end{array}$ & $4 / 9(44)$ & $16 / 16(100)^{\dagger}$ & $4 / 7(57)$ \\
\hline $\begin{array}{l}14 \text { (14): no. with titer } \geq \text { LLOQ/no. } \\
\text { with level } \geq \text { LLOQ at baseline (\%)* }\end{array}$ & $22 / 22(100)$ & $20 / 21(95)$ & $18 / 19(95)$ \\
\hline $\begin{array}{l}19 \text { (19F): no. with titer } \geq \text { LLOQ/no. } \\
\text { with level } \geq \text { LLOQ at baseline }(\%)^{*}\end{array}$ & $23 / 23(100)$ & $22 / 22(100)$ & $15 / 16(94)$ \\
\hline $\begin{array}{l}23(23 \mathrm{~F}) \text { : no. with titer } \geq \text { LLOQ } / \text { no. } \\
\text { with level } \geq \text { LLOQ at baseline }(\%)^{*}\end{array}$ & $19 / 20(95)$ & $20 / 21(95)$ & $14 / 14(100)$ \\
\hline $\begin{array}{l}26 \text { (6B): no. with titer } \geq \mathrm{LLOQ} / \text { no. } \\
\text { with level } \geq \text { LLOQ at baseline }(\%)^{*}\end{array}$ & $17 / 17(100)$ & $21 / 22(96)$ & $11 / 13(85)$ \\
\hline $\begin{array}{l}51 \text { (7F): no. with titer } \geq \mathrm{LLOQ} / \text { no. } \\
\text { with level } \geq \text { LLOQ at baseline }(\%)^{*}\end{array}$ & $20 / 20(100)$ & $26 / 26(100)$ & $17 / 19(90)$ \\
\hline $\begin{array}{l}56(18 \mathrm{C}) \text { : no. with titer } \geq \mathrm{LLOQ} / \text { no. } \\
\text { with level } \geq \text { LLOQ at baseline }(\%)^{*}\end{array}$ & $22 / 23(96)$ & $24 / 24(100)$ & $17 / 17(100)$ \\
\hline Tetanus toxin, $\mathrm{n}^{\dagger \dagger}$ & 33 & 32 & 23 \\
\hline $\begin{array}{l}\text { No. with titer } \geq 0.50 \mathrm{IU} / \mathrm{ml} / \mathrm{no} \text {. with } \\
\text { titer } \geq 0.50 \mathrm{IU} / \mathrm{ml} \text { at baseline }(\%)\end{array}$ & $22 / 26(85)$ & $24 / 25(96)$ & $11 / 14(79)$ \\
\hline Influenza antigens, $2006-7$ vaccine, $\mathrm{n}{ }^{\dagger \dagger}$ & 16 & 23 & 12 \\
\hline $\begin{array}{l}\text { New Caledonia: no. with titer }>1: 10 / \text { no. } \\
\text { with level }>1: 10 \text { at baseline }(\%)\end{array}$ & $15 / 16(94)$ & $21 / 22(96)$ & $12 / 12(100)$ \\
\hline $\begin{array}{l}\text { Wisconsin: no. with titer > 1:10/no. } \\
\text { with level > 1:10 at baseline (\%) }\end{array}$ & $16 / 16(100)$ & $22 / 22(100)$ & $12 / 12(100)$ \\
\hline $\begin{array}{l}\text { Malaysia: no. with titer } \geq 1: 10 / \text { no. } \\
\text { with level }>1: 10 \text { at baseline }(\%)\end{array}$ & $16 / 16(100)$ & $22 / 22(100)$ & $11 / 11(100)$ \\
\hline Influenza antigens, $2007-8$ vaccine, $\mathrm{n}^{\dagger \dagger}$ & 29 & 40 & 27 \\
\hline $\begin{array}{l}\text { Solomon Island 1,2,3: no. with titer }> \\
1: 10 / \text { no. with level }>1: 10 \text { at baseline }(\%)\end{array}$ & $28 / 28(100)$ & $39 / 39(100)$ & $27 / 27(100)$ \\
\hline $\begin{array}{l}\text { Wisconsin 1,2,3: no. with titer }>1: 10 / \text { no. } \\
\text { with level }>1: 10 \text { at baseline }(\%)\end{array}$ & $29 / 29(100)$ & $39 / 39(100)$ & $25 / 25(100)$ \\
\hline $\begin{array}{l}\text { Malaysia 1,2,3: no. with titer }>1: 10 / \text { no. } \\
\text { with level }>1: 10 \text { at baseline }(\%)\end{array}$ & $28 / 28(100)$ & $33 / 34(97)$ & $26 / 27(93)$ \\
\hline
\end{tabular}

\footnotetext{
* No. with antipneumococcal $\operatorname{IgG}$ level $\geq 0.3 \mu \mathrm{g} / \mathrm{ml}$ at Week $52 / \mathrm{no}$. with level $\geq 0.3 \mu \mathrm{g} / \mathrm{ml}$ at baseline; ${ }^{\dagger} \mathrm{p}<0.05$. ${ }^{\dagger}$ Numbers of patients with data available. The $\mathrm{p}$ values for comparison of proportions of patients maintaining antibody levels $\geq$ LLOQ or achieving adequate response levels are from Fisher's exact test for belimumab vs placebo. IgG: immunoglobulin G: LLOQ: lower limit of quantitation.
}

2008-9 vaccine (Table 4). Increases in titers were greater in patients with placebo, with significant differences compared to patients receiving belimumab $1 \mathrm{mg} / \mathrm{kg}$ for the Brisbane-10 and Brisbane-59 strains and compared to patients with belimumab $10 \mathrm{mg} / \mathrm{kg}$ for the Brisbane-59 strain. Postvaccination, titers were maintained in all patients with placebo and belimumab $10 \mathrm{mg} / \mathrm{kg}$; in patients with belimumab $1 \mathrm{mg} / \mathrm{kg}$, titer levels $>1: 10$ were not achieved against the Brisbane-10 strain in 1 patient and against the Brisbane-59 strain in 3 patients.

Changes in memory $B$ cells and occurrence of infections. Memory B cell levels peaked at Week 8 , with mean percentage changes from baseline of $23 \%$ with placebo, $150 \%$ with belimumab $1 \mathrm{mg} / \mathrm{kg}$, and $191 \%$ with belimumab 
Placebo 口Belimumab 1 mg/kg 口Belimumab 10 mg/kg

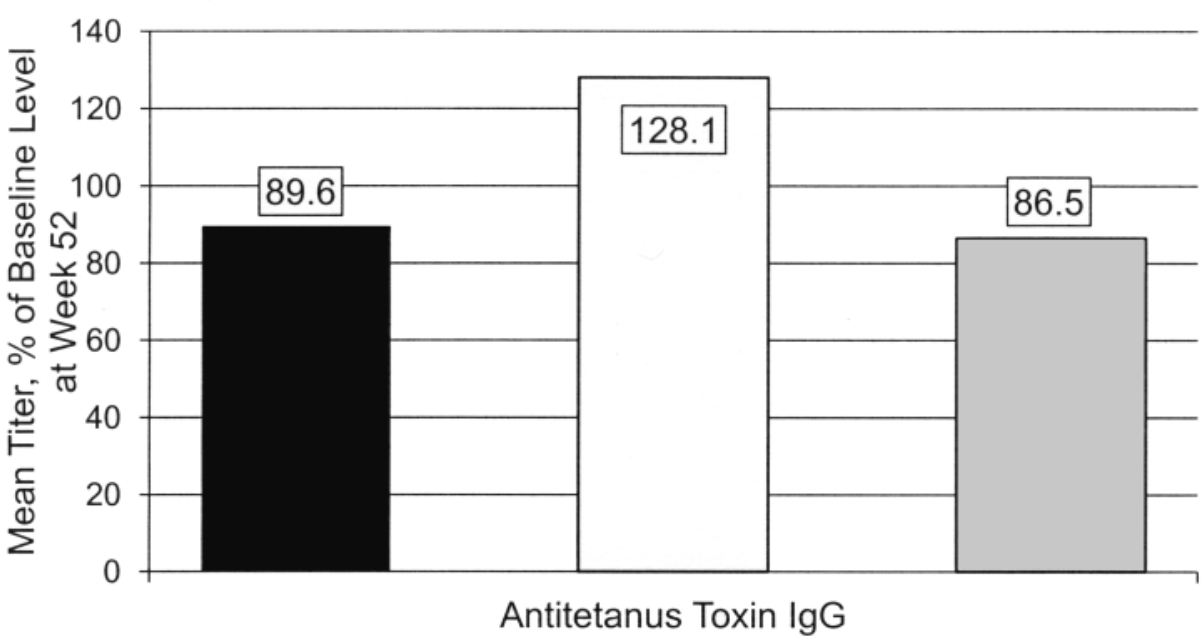

Figure 2. Antitetanus toxoid immunoglobulin $\mathrm{G}(\mathrm{IgG})$ titers at Week 52 as percentages of baseline levels in patients who received tetanus vaccination prior to Day 0 and who were not revaccinated during the study.

Table 3. Percentage changes in antiinfluenza immunoglobulin G titers at Week 52 compared with baseline in patients who received influenza vaccination prior to Day 0 who were not revaccinated during the study.

\begin{tabular}{|c|c|c|c|}
\hline & $\begin{array}{c}\text { Standard Therapy }+ \\
\text { Placebo }\end{array}$ & $\begin{array}{c}\text { Standard Therapy }+ \\
\text { Belimumab } \\
1 \mathrm{mg} / \mathrm{kg}\end{array}$ & $\begin{array}{c}\text { Standard Therapy }+ \\
\text { Belimumab } \\
10 \mathrm{mg} / \mathrm{kg}\end{array}$ \\
\hline Influenza antigens, $2006-7$ vaccine, $\mathrm{n}^{\dagger \dagger}$ & 16 & 23 & 12 \\
\hline $\begin{array}{l}\text { New Caledonia: mean IgG \% change in } \\
\text { titer at Week } 52(\mathrm{SE})\end{array}$ & $31.8(17.2)$ & $24.5(20.3)$ & $1.2(19.0)$ \\
\hline Median & 0.0 & 0.0 & -18.2 \\
\hline $\begin{array}{l}\text { Wisconsin: mean IgG \% change in } \\
\text { titer at Week } 52 \text { (SE) }\end{array}$ & $901.9(788.1)$ & $4.8(16.8)^{*}$ & $-11.4(12.3)^{*}$ \\
\hline Median & 0.0 & 0.0 & 0.0 \\
\hline $\begin{array}{l}\text { Malaysia: mean IgG \% change in } \\
\text { titer at Week } 52(\mathrm{SE})\end{array}$ & $40.4(17.5)$ & $-13.0(7.7)^{*}$ & $520.8(525.5)$ \\
\hline Median & 0.0 & 0.0 & 0.0 \\
\hline Influenza antigens, $2007-8$ vaccine, $\mathrm{n}^{\dagger \dagger}$ & 29 & 40 & 27 \\
\hline $\begin{array}{l}\text { Solomon Island } 1,2,3(\mathrm{n}=39) \text { : mean } \\
\text { IgG } \% \text { change in titer at Week } 52(\mathrm{SE})\end{array}$ & $2.6(26.3)$ & $-7.5(11.2)$ & $-8.7(16.5)$ \\
\hline Median & -20.6 & -20.0 & -37.5 \\
\hline $\begin{array}{l}\text { Wisconsin } 1,2,3(\mathrm{n}=26) \text { : mean } \operatorname{IgG} \% \\
\text { change in titer at Week } 52(\mathrm{SE})\end{array}$ & $63.1(36.9)$ & $27.1(20.2)$ & $-4.9(15.1)$ \\
\hline Median & 0.0 & 0.0 & -20.6 \\
\hline $\begin{array}{l}\text { Malaysia 1,2,3: mean IgG \% change } \\
\text { in titer at Week } 52(\mathrm{SE})\end{array}$ & $-7.8(11.3)$ & $-4.7(7.6)$ & $-32.0(5.5)$ \\
\hline Median & 0.0 & 0.0 & -50.0 \\
\hline
\end{tabular}

$* \mathrm{p}<0.05 .{ }^{\dagger \dagger}$ Numbers of patients with data available. The $\mathrm{p}$ values are from Wilcoxon rank-sum test for belimumab versus placebo. IgG: immunoglobulin G; SE: standard error.

$10 \mathrm{mg} / \mathrm{kg}$; the corresponding mean changes were $21 \%$, $108 \%$, and $89 \%$ at Week 52 , and $22 \%, 52 \%$, and $71 \%$ at Week 76 . These increases in the vaccine substudy population were similar to those observed in the overall BLISS-76 population ${ }^{9}$.

In the overall BLISS-76 study population, serious or severe cases of pneumonia occurred in $1.9 \%$ of patients with placebo, $1.8 \%$ with belimumab $1 \mathrm{mg} / \mathrm{kg}$, and $2.9 \%$ with belimumab $10 \mathrm{mg} / \mathrm{kg}$; none had documented pneumococcal pneumonia infections, but the causal organism was not always identified. Serious or severe cases of influenza occurred in $0.4 \%, 0.0 \%$, and $0.4 \%$ of patients with placebo and belimumab $1 \mathrm{mg} / \mathrm{kg}$ and $10 \mathrm{mg} / \mathrm{kg}$, respectively. No serious/severe cases of tetanus were reported. 
Table 4. Effect of placebo or belimumab plus standard therapy on anti-influenza IgG levels in patients receiving on-study influenza vaccination in BLISS-76.

\begin{tabular}{|c|c|c|c|}
\hline & $\begin{array}{c}\text { Standard Therapy + } \\
\text { Placebo }\end{array}$ & $\begin{array}{c}\text { Standard Therapy }+ \\
\text { Belimumab } \\
1 \mathrm{mg} / \mathrm{kg}\end{array}$ & $\begin{array}{c}\text { Standard Therapy }+ \\
\text { Belimumab } \\
10 \mathrm{mg} / \mathrm{kg}\end{array}$ \\
\hline $2007-8$ vaccine, $\mathrm{n}{ }^{\dagger \dagger}$ & 10 & 13 & 7 \\
\hline $\begin{array}{l}\text { Solomon Island } 1,2,3 \text { : mean IgG } \% \text { change } \\
\text { pre- to postvaccination (SE) }\end{array}$ & $1774.6(1240.0)$ & $791.1(474.4)$ & $318.1(118.5)$ \\
\hline Median & 300.0 & 300.0 & 300.0 \\
\hline $\begin{array}{l}\text { No. with antibody titer }>1: 10 / \text { no. without } \\
\text { titer }>1: 10 \text { prevaccination }(\%)\end{array}$ & $0 / 0$ & $1 / 1(100)$ & $0 / 0$ \\
\hline $\begin{array}{l}\text { No. with antibody titer }>1: 10 / \text { no. with tite } \\
>1: 10 \text { prevaccination }(\%)\end{array}$ & iter $10 / 10(100)$ & $12 / 12(100)$ & $7 / 7(100)$ \\
\hline $\begin{array}{l}\text { Wisconsin } 1,2,3 \text { : mean IgG } \% \text { change pre- } \\
\text { to postvaccination (SE) }\end{array}$ & $8410.8(7816.5)$ & $692.1(419.2)$ & $94.9(42.4)$ \\
\hline Median & 158.7 & 217.5 & 33.3 \\
\hline $\begin{array}{l}\text { No. with antibody titer }>1: 10 / \text { no. without } \\
\text { titer }>1: 10 \text { prevaccination }(\%)\end{array}$ & $0 / 0$ & $1 / 1(100)$ & $0 / 0$ \\
\hline $\begin{array}{l}\text { No. with antibody titer }>1: 10 / \text { no. with tite } \\
>1: 10 \text { prevaccination }(\%)\end{array}$ & iter $10 / 10(100)$ & $12 / 12(100)$ & $7 / 7(100)$ \\
\hline $\begin{array}{l}\text { Malaysia 1,2,3: mean IgG } \% \text { change pre- to } \\
\text { postvaccination (SE) }\end{array}$ & $326.7(145.3)$ & $131.2(40.4)$ & $3749.9(3626.2)$ \\
\hline Median & 183.5 & 100.0 & 100.0 \\
\hline $\begin{array}{l}\text { No. with antibody titer }>1: 10 / \text { no. without } \\
\text { titer }>1: 10 \text { prevaccination }(\%)\end{array}$ & $0 / 0$ & $\mathrm{NA} / 1$ & $1 / 1(100)$ \\
\hline $\begin{array}{l}\text { No. with antibody titer }>1: 10 / \text { no. with } \\
\text { titer }>1: 10 \text { prevaccination }(\%)\end{array}$ & $10 / 10(100)$ & $12 / 12(100)$ & $6 / 6(100)$ \\
\hline $2008-9$ vaccine, $\mathrm{n}^{\dagger \dagger}$ & 16 & 24 & 14 \\
\hline $\begin{array}{l}\text { Brisbane-10 1,2,3: mean IgG \% change pre- } \\
\text { to postvaccination (SE) }\end{array}$ & - $1445.8(420.7)$ & $225.4(72.0)^{*}$ & $610.6(216.8)$ \\
\hline Median & 744.5 & 100.0 & 258.7 \\
\hline $\begin{array}{l}\text { No. with antibody titer }>1: 10 / \text { no. without } \\
\text { titer }>1: 10 \text { prevaccination }(\%)\end{array}$ & $4 / 4(100)$ & $5 / 6(83)$ & $1 / 1(100)$ \\
\hline $\begin{array}{l}\text { No. with antibody titer }>1: 10 / \text { no. with tite } \\
>1: 10 \text { prevaccination }(\%)\end{array}$ & iter $12 / 12(100)$ & $18 / 18(100)$ & $13 / 13(100)$ \\
\hline $\begin{array}{l}\text { Brisbane-59 1,2,3: mean IgG } \% \text { change pre- } \\
\text { to postvaccination (\%) }\end{array}$ & $818.9(388.8)$ & $318.7(134.0)^{\dagger}$ & $219.1(139.6)^{*}$ \\
\hline Median & 258.7 & 100.0 & 18.5 \\
\hline $\begin{array}{l}\text { No. with antibody titer }>1: 10 / \text { no. without } \\
>1: 10 \text { prevaccination }(\%)\end{array}$ & ut titer 3/3 (100) & $5 / 8(62.5)$ & $1 / 1(100)$ \\
\hline $\begin{array}{l}\text { No. with antibody titer }>1: 10 / \text { no. with tite } \\
1: 10 \text { prevaccination }(\%)\end{array}$ & iter $>13 / 13(100)$ & $16 / 16(100)$ & $13 / 13(100)$ \\
\hline $\begin{array}{l}\text { Florida: mean } \operatorname{IgG} \% \text { change pre- to } \\
\text { postvaccination (SE) }\end{array}$ & $896.6(417.9)$ & $301.0(129.4)$ & $282.3(121.0)$ \\
\hline Median & 125.9 & 100.0 & 100.0 \\
\hline $\begin{array}{l}\text { No. with antibody titer }>1: 10 / \text { no. without } \\
\text { titer }>1: 10 \text { prevaccination }(\%)\end{array}$ & $1 / 1(100)$ & $1 / 1(100)$ & $0 / 0$ \\
\hline $\begin{array}{l}\text { No. with antibody titer }>1: 10 / \text { no. with } \\
\text { titer }>1: 10 \text { prevaccination }(\%)\end{array}$ & $15 / 15(100)$ & $23 / 23(100)$ & $14 / 14(100)$ \\
\hline
\end{tabular}

In the vaccine substudy, 8 cases of influenza were reported in 7 of 73 patients $(9.7 \%)$ with placebo, 1 of which was severe. Of the 7 patients, 3 had received on-study vaccinations, 1 of whom had been vaccinated twice on study. In the belimumab $1 \mathrm{mg} / \mathrm{kg}$ group, 6 of 89 patients (6.7\%) experienced 8 cases of influenza ( 1 patient had influenza 3 times).
All 8 cases were considered mild or moderate, and only 1 patient had on-study vaccination. In the belimumab 10 $\mathrm{mg} / \mathrm{kg}$ group, 2 of 73 patients (2.7\%) were diagnosed with mild influenza and neither had received on-study vaccination.

In the vaccine substudy, pneumonia was reported in 2 of 
73 patients (2.7\%) with placebo ( 1 of whom had 2 cases), 3 of $89(3.4 \%)$ with belimumab $1 \mathrm{mg} / \mathrm{kg}$, and 0 with belimumab $10 \mathrm{mg} / \mathrm{kg}$. All pneumonia infections were designated mild or moderate. Only 1 patient in the belimumab $1 \mathrm{mg} / \mathrm{kg}$ group had been vaccinated on study, $\sim 5$ months prior to the pneumonia diagnosis; antipneumococcal $\operatorname{IgG}$ titer levels assessed $\sim 3$ months prior to pneumonia onset were $\geq$ LLOQ for all 12 antigens.

\section{DISCUSSION}

Consistent with preservation of memory B cells with belimumab, belimumab treatment in patients with SLE did not affect preexisting antibody responses to pneumococcal, tetanus, or influenza vaccines, with similar proportions of patients receiving placebo and belimumab maintaining antibody titers that are considered protective against future infections in the time frame studied. In the small number of patients receiving pneumococcal vaccine on study, responses did not appear to differ between treatment groups, with responses to the majority of antigens being observed in all patients. Most of the small number of patients receiving tetanus vaccine on study had titers above the threshold for an immune response both before and after vaccination. Interpretation of findings in patients receiving influenza vaccine on study is confounded by the inclusion of the same influenza strains in consecutive seasonal vaccines, resulting in many patients having preexisting antibodies to at least 1 of the tested antigens. The majority of patients, however, had antibody titers $>1: 10$ at Week 52 . For the 2007-8 vaccine, responses were observed for all antigens in all patients with data available. For the 2008-9 vaccine, antibody responses were lower with belimumab, but titer levels > 1:10 against all antigens were achieved in all patients with belimumab $10 \mathrm{mg} / \mathrm{kg}$ and in 21 of 24 patients with $1 \mathrm{mg} / \mathrm{kg}$. Across the 2 years during which patients received on-study vaccinations, 24 of 29 patients without preexisting antibody titers $>1: 10$ for $\geq 1$ antigen were able to mount a response to that antigen. The quantitatively reduced specific antibody response to the 2008-9 influenza vaccine is consistent with the impaired humoral response to influenza vaccination in patients with rheumatoid arthritis receiving rituximab, a monoclonal antibody-targeting B cell CD20 protein ${ }^{16,17,18,19}$.

Belimumab treatment was not associated with increased risk of serious/severe infections in BLISS-76 ${ }^{4}$. Among 275 patients with placebo, 271 with belimumab $1 \mathrm{mg} / \mathrm{kg}$, and 273 with belimumab $10 \mathrm{mg} / \mathrm{kg}$, infection of any grade occurred as an adverse event in $69.1 \%, 74.5 \%$, and $74.0 \%$; was serious in $5.8 \%, 7.0 \%$, and $7.3 \%$; was severe in $4.0 \%$, $3.0 \%$, and $2.6 \%$; and was the cause of discontinuation of study treatment in $1.8 \%, 0.7 \%$, and $0.4 \%$, respectively. In addition to preservation of the memory B cell compartment observed with belimumab treatment in BLISS-76, T cell populations were maintained throughout the study in patients receiving belimumab, suggesting preservation of cellular immunity ${ }^{4}$. Together, these findings appear to account for the absence of increased risk for serious/severe infection in patients with belimumab in this trial, including no apparent increased risk for pneumonia, tetanus, or influenza.

One of the major limitations of our substudy is the small number of patients who received on-study pneumococcal and tetanus vaccines. In addition, the results regarding on-study influenza vaccines are confounded by inclusion of the same influenza strains in consecutive seasonal vaccines. Further, patients had variable time periods between prestudy vaccinations and treatment with belimumab in BLISS-76, and patients with on-study vaccinations received them at different timepoints during the study, leading to variable exposure to belimumab.

Belimumab treatment did not affect preexisting antibody responses to pneumococcal, tetanus, or influenza vaccines in patients with SLE in the BLISS-76 trial. There also did not appear to be substantially increased risk of an inadequate response to influenza vaccine given during belimum$\mathrm{ab}$ treatment. Further study is necessary to more fully characterize the adequacy of antibody responses to vaccines given during belimumab therapy.

\section{ACKNOWLEDGMENT}

The authors thank Matt Stenger and Eleanore Gross of BioScience Communications, New York, New York, for editorial support.

\section{REFERENCES}

1. O'Neill SG, Isenberg DA. Immunizing patients with systemic lupus erythematosus: A review of effectiveness and safety. Lupus 2006; $15: 778-83$.

2. Mathian A, Devilliers H, Krivine A, Costedoat-Chalumeau N, Haroche J, Boutin-Le Thi Huong D, et al. Factors influencing the efficacy of two injections of a pandemic 2009 influenza A (H1N1) nonadjuvanted vaccine in systemic lupus erythematosus. Arthritis Rheum 2011;63:3502-11.

3. Navarra SV, Guzmán RM, Gallacher AE, Hall S, Levy RA, Jimenez RE, et al. Efficacy and safety of belimumab in patients with active systemic lupus erythematosus: A randomised, placebo-controlled, phase 3 trial. Lancet 2011;377:721-31.

4. Furie R, Petri M, Zamani O, Cervera R, Wallace DJ, Tegzová D, et al. A phase III, randomized, placebo-controlled study of belimumab, a monoclonal antibody that inhibits B lymphocyte stimulator, in patients with systemic lupus erythematosus. Arthritis Rheum 2011;63:3918-30.

5. Do RK, Hatada E, Lee H, Tourigny MR, Hilbert D, Chen-Kiang S. Attenuation of apoptosis underlies B lymphocyte stimulator enhancement of humoral immune response. J Exp Med 2000;192:953-64.

6. Harless SM, Lentz VM, Sah AP, Hsu BL, Clise-Dwyer K, Hilbert $\mathrm{DM}$, et al. Competition for BLyS-mediated signaling through $\mathrm{Bcmd} / \mathrm{BR} 3$ regulates peripheral B lymphocyte numbers. Curr Biol 2001;11:1986-9.

7. Moore PA, Belvedere O, Orr A, Pieri K, LaFleur DW, Feng P, et al. BLyS: member of the tumor necrosis family and B lymphocyte stimulator. Science 1999;285:260-3.

8. Baker KP, Edwards BM, Main SH, Choi GH, Wager RE, Halpern WG, et al. Generation and characterization of LymphoStat-B, a 
human monoclonal antibody that antagonizes the bioactivities of B lymphocyte stimulator. Arthritis Rheum 2003;48:3253-65.

9. Stohl W, Hiepe F, Latinis KM, Thomas M, Scheinberg MA, Clarke A, et al. Belimumab reduces autoantibodies, normalizes low complement, and reduces select B-cell populations in patients with systemic lupus erythematosus. Arthritis Rheum 2012 Jan 24 (E-pub ahead of print).

10. Galazka AM. The immunological basis for immunization series. Module 3: Tetanus. Geneva: World Health Organization; 1993. [Internet. Accessed May 3, 2012.] Available from: http://www.who.int/vaccines-documents/DocsPDF-IBI-e/mod3_e.pdf

11. World Health Organization. Immunizations, vaccines and biologicals: Pneumococcal vaccines. 2003. [Internet. Accessed May 3, 2012.] Available from: http://www.who.int/vaccines/en/ pneumococcus.shtml

12. World Health Organization. Initiative for vaccine research (IVR). Acute respiratory infections. Influenza. 2009. [Internet. Accessed May 3, 2012.] Available from: http://www.who.int/vaccine_research/diseases/ari/en/index 1.html research/diseases/ari/en/index 1.html

13. Treanor J, Wright PF. Immune correlates of protection against influenza in the human challenge model. Dev Bio 2003;115:97-104.

14. Wallace DJ, Stohl W, Furie RA, Lisse JR, McKay JD, Merrill JT, et al. A phase II, randomized, double-blind, placebo-controlled, dose-ranging study of belimumab in patients with active systemic lupus erythematosus. Arthritis Rheum 2009;61:1168-78.
15. Centers for Disease Control and Prevention. Prevention of pneumococcal disease: Recommendations of the Advisory Committee on Immunization Practices (ACIP). Morb Mortal Wkly Rep 1997;46:1-24.

16. Arad U, Tzadok S, Amir S, Mandelboim M, Mendelson E, Wigler I, et al. The cellular immune response to influenza vaccination is preserved in rheumatoid arthritis patients treated with rituximab. Vaccine 2011;29:1643-8.

17. Elkayam O, Bashkin A, Mandelboim M, Litinsky I, Comaheshter D, Levartovsky D, et al. The effect of infliximab and timing of vaccination on the humoral response to influenza vaccination in patients with rheumatoid arthritis and ankylosing spondylitis. Semin Arthritis Rheum 2010;39:442-7.

18. Rehnberg M, Brisslert M, Amu S, Zendjanchi K, Håwi G, Bokarewa M. Vaccination response to protein and carbohydrate antigens in patients with rheumatoid arthritis after rituximab treatment. Arthritis Res Ther 2010;12:R111.

19. van Assen S, Holvast A, Benne CA, Posthumus MD, van Leeuwen MA, Voskuyl AE, et al. Humoral responses after influenza vaccination are severely reduced in patients with rheumatoid arthritis treated with rituximab. Arthritis Rheum 2010;62:75-81. 